\title{
Parameters for Use of Waste Castor-Oil Seed (Ricinus communis) as Biomass
}

\author{
Javier E. Rodríguez-Yáñez \\ Laboratorio de Ecología Urbana, Universidad Estatal a Distancia (UNED), \\ Mercedes de Montes de Oca, San José, Costa Rica \\ jrodriguezy@uned.ac.cr
}

Received date:9 January 2019; Accepted date:20 May 2019; Published date: 23 July 2019

Academic Editor: Luis Héctor Quintero Hernández

Copyright (C) 2019. Javier E. Rodríguez-Yáñez. Distributed under Creative Commons CC-BY 4.0

\begin{abstract}
The culture of castor bean use is growing in Latin America. After extracting the oil, the biomass waste is considered for energy based on its thermal energy potential of about 18 $\mathrm{kJ}{ }^{*} \mathrm{~g}-1$. When using biomass, it is important for the product to be dry, both for its conservation and efficient use. The castor bean is separated into its three basic parts (outer shell, inner shell and seed), before processing the seed to obtain oil. This study researches the differences between these three parts, associated to basic physicochemical parameters to use them as biomass. The drying curves suggest that each part of the castor been has a different $\mathrm{xC}$, which conditions the variables associated with the fluxional area and the kinetic constant of the superficial drying region on islands. The energy required for drying depends mainly on the maximum absorbable humidity of the sample, which is $60 \%$ (wet basis moisture content), for the outer shell and the seed, but only $33 \%$ for the inner shell. The useful drying energy dependents on the absorbable moisture, so it has a similar dependence with values of the order of 1,5 to $1,3 \mathrm{MJ}{ }^{*} \mathrm{~kg}-1$ for the outer shell and the seed, but only $0,75 \mathrm{MJ}{ }^{*} \mathrm{~kg}-1$ for the internal shell. The evaluation made by thermogravimetry in nitrogen shows a concentrated main decomposition for all the samples in areas of the order of 150 to $400{ }^{\circ} \mathrm{C}$, with\% of variation of mass from 30 to $35 \%$.
\end{abstract}

Keywords: Ricinus communis, biomass, drying energy, thermal energy potential

\section{Introduction}

The Ricinus communis is a plant characteristic of the tropical and temperate areas. In some countries they have different names (ricino, tartago, higuerilla, mamona, among others) and present specific appearance (Rivera Brenes, 2014).
It is used mainly to obtain castor oil from its seed. This process involves as a first stage a drying process, usually carried out naturally in the yard, which is necessary mainly to avoid the rot of the seed and its capsule. This methodology does not allow a clear understanding of drying process (Goneli et al., 2016; Embrapa Algodão, 2015).

Cite this Article as: Javier E. Rodríguez-Yáñez (2019)," Parameters for Use of Waste Castor-Oil Seed (Ricinus communis) as Biomass" International Journal of Renewable Energy and Biofuels, Vol. 2019 (2019), Article ID 529157, DOI: 10.5171/2019.529157 
After the oil processes, the biomasic waste is used in different recovery processes to obtain energy, bio diesel, animal food, compost, paper, water retenders, etc. (Corredor Becerra, 2008; Escoto García, Rutiaga Quiñones, Orihuela Equihua, Rodríguez Rivas, \& Rivera Prado, 2014; Sánchez S., Castañeda S., \& Castañeda S. 2016; da Silva T. et al., 2018; Karmakar B. et al., 2018).

In Latin America the area of this crop is growing, and it is considered know how the drying process is, for the complete castor oil seed and his parts (Salazar Sanchez, et al., 2015).
Under this premise, the following work is developed, considering in this stage drying curves and other physicochemical aspects related to combustion or pyrolysis associated with the parts of the seed.

\section{Methods}

The seeds used are of type ColBio 09, planted in Costa Rica, in the South Pacific region of the country.

They were previously dried in the yard for their conservation and separated into their basic components: outer shell, internal shell and seed. (see figure 1) a)

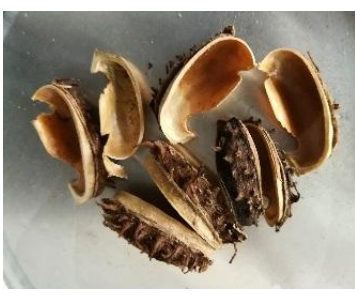

b)

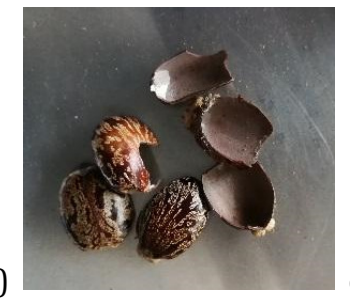

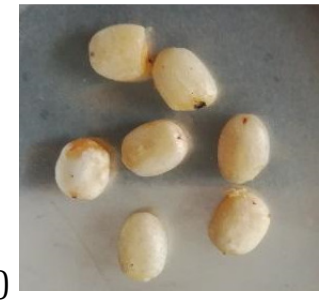

Figure 1: Components of castor oil seed: a) outer shell, b) internal shell, c) seed

\section{Grinding}

All the components, previously separated, were gridding in a knife mill, brand Restech, model SM 100, to obtain size les that Mesh 20 (less than $0,84 \mathrm{~mm}$ ). The seed was milled to obtain size less that Mesh 100 (less than $0,15 \mathrm{~mm}$ ). The seed was processed to extract castor oil with ethyl alcohol. The seed without oil was softly heated to eliminate the residual alcohol.

\section{Drying curves}

Each of the milled components was moistened for 14 hours to obtain complete saturation of water. After that, the excess water was eliminated with vacuum filter system and the remnant with absorbent paper.

Approximately $10 \mathrm{~g}$ of the sample were weighed in a drying scale, brand OHAUS, model MB 35. This drying scale was previously stabilized to $50^{\circ} \mathrm{C}$ for 30 minutes. The drying process was started measuring the mass as a function of time, to constant weight or a variation of less than 1 $\mathrm{mg}$ for 1 minute. The curve is obtained with measures at short times at the beginning that become more spaced along the measurement.

The whole system is in an environment with a temperature of $25^{\circ} \mathrm{C}, 60 \%$ relative humidity and a local pressure of $87 \mathrm{kPa}$.

The equations and classic considerations for the drying in conditions of a constant temperature are presented (Geankoplis, 2003).

Different drying parameters are obtained from the curves according to the drying stage: 
- In stage 1, or surface water drying, the critical time ( $\left.\mathrm{tc}_{\mathrm{c}}\right)$ and the associated critical moisture fraction $\left(x_{\mathrm{C}}\right)$ are obtained, as well as the surface water evaporation rate $\left(\mathrm{d} x / \mathrm{dt}\right.$ in $\left.\mathrm{t}_{\mathrm{C}}\right)$, as well as the fluxional area (Aflux

- In stage 2, or drying of surface water with dry islands, the kinetic constant specific first order ( $\left.\mathrm{k}_{\mathrm{esp}}\right)$ is obtained, as well as the moisture fraction at the end of the stage $\left(X_{\mathrm{D}}\right)$ and its corresponding time $\left(t_{D}\right)$

- From the overall drying curve (1- $x$ vs $t$ ) the general drying equation is obtained, as a polynomial of third degree and the energy associated to the process (E vs 1- $x$ ).

The moisture fraction is determined according to:

Where:

$\mathrm{mt}$ is the mass at time $\mathrm{t}$

$\mathrm{mt}_{0}$ is the initial mass

$\mathrm{mt}_{\propto}$ is the infinite time mass or the dry sample

From the curve $x$ vs $t$ we obtain the polynomial of approximation to this by minimum squares, which is usually considered to be of the third degree, usually with a $\mathrm{R}>0,99$.

The xc or fraction of critical humidity is determined when the curve of the mass with respect to time ( $\mathrm{m}$ vs $\mathrm{t}$ ) stops being linear $(R<0,999)$ in the initial values of measurement, and the slope in the curve ($\mathrm{dm} / \mathrm{dt}$ ), in $x_{\mathrm{C}}$, is the rapidity of evaporation in the stage or region 1 , generally expressed in terms of $\mathrm{d} x / \mathrm{dt}$.

The fluxional area (Aflux) is an estimate of the evaporation surface. It is determined based on the rate of evaporation of water ( $r$ ) in the drying balance at the working temperature $\left(50^{\circ} \mathrm{C}\right)$ whose value is 11,37 $\mathrm{mol}^{*} \mathrm{~s}^{-1 *} \mathrm{~m}^{-2}$ and the evaporation rate in biomass as dm/dt in $\mathrm{mg}^{*} \mathrm{~min}^{-1}$. Where $\mathrm{A}_{\text {flux }}=$ $(\mathrm{dm} / \mathrm{dt}) / \mathrm{r}$, with units of $\mathrm{m}^{2}$. Usually this is divided by the final mass or mass at infinite time $\left(\mathrm{mt}_{\propto}\right)$ to obtain a specific fluxional area in $\mathrm{m}^{2 *} \mathrm{~kg}^{-1}$.

The value of the kinetic constant $(\mathrm{k})$ of stage 2 is determined from the curve $\mathrm{d} x / \mathrm{dt}$ vs (1$x$ ), where the linear slope in this stage ( $\mathrm{R}$ $<0,999$ ) is associated with the value of $k$. The point where the curve stops being linear is associated with $x_{\mathrm{D}}$ and $t_{D}$. Corrections are made to express $\mathrm{k}$ in usual dimensions of $\mathrm{k}_{\mathrm{esp}}$ in $\mathrm{s}^{-1} * \mathrm{~m}^{-2}$, dividing it by the fluxional area.

The useful energy of the drying process is obtained according to the methodology described by Puente-Urbina et al (2016), based on the energy of the equipment and an efficiency factor associated with the amount of water in the sample. Under these considerations, the fraction of energy required for the removal of non-surface water is calculated, usually expressed as a useful 1-E $x_{C} / E_{u s e f u l}$. The fraction of energy for the removal of strongly bound water is also calculated, such as 1- E $X_{\mathrm{D}} /$ Euseful.

\section{Calorific power, humidity and ashes}

The calorific power of the samples was carried out with a Parr Oxygen calorimetric bomb, model A50N, on the crushed and dried samples previously in a Radwag moisture analyzer, model PMC50. The presented values are superior calorific powers. The ashes are obtained by drying and calcination of the samples crushed at $550^{\circ} \mathrm{C}$, in a muffle brand Furnace Thermolyne Sybbon, Model 30400, until constant mass. 


\section{Thermogravimetry (TGA)}

The TGA curves were performed in a TGAQ500 equipment, model V.20, with a flow of $90 \mathrm{ml}^{*} \mathrm{~min}^{-1}$ of nitrogen 5.0, with a temperature ramp of $20{ }^{\circ} \mathrm{C}^{*} \mathrm{~min}^{-1}$, from room temperature to $1000{ }^{\circ} \mathrm{C}$.

The test is carried out from a dry sample of each of the components of the seed, with particle sizes less than Mesh 100 mesh.

The variation of the mass (\% masses) is evaluated with time (or temperature) and the speed of variation $\left(\%\right.$ mass $\left.{ }^{*}{ }^{\circ} \mathrm{C}^{-1}\right)$. The main variation range is evaluated based on the speed of variation, considering the start and end of the variation based on values of speed.
These types of tests allow appreciating the decomposition process of the biomass in non-oxidizing media $\left(\mathrm{N}_{2}\right)$. Indirectly, an approximate value of residual moisture and ash is also obtained.

\section{Results and Discussion}

\section{Drying Curves}

Table 1 shows the average variables obtained for each type of part of the castor seed, considering the main values: apparent density (d app), \% RH, tc, $x_{\mathrm{c}}, \mathrm{dm} / \mathrm{dt}$, Specific fluxional area, $t_{D}, x_{D}$, k specific, Total energy for drying ( $E_{\text {Total }}$ ), Energy used to evaporate water $\left(E_{u s e f u l}\right)$, Energy used to reach $x_{\mathrm{C}}\left(\mathrm{E} x_{\mathrm{C}}\right)$, Energy used to reach $x_{\mathrm{D}}\left(\mathrm{E} x_{\mathrm{D}}\right)$ and energy fractions: 1-E $x_{\mathrm{C}} / \mathrm{E}_{\mathrm{useful}}$ and 1-E $x_{\mathrm{D}} / \mathrm{E}_{\text {useful }}$

Table 1: Data of the drying curve for castor bean seed samples

\begin{tabular}{|c|c|c|c|}
\hline Sample & Outer Shell & Internal Shell & $\begin{array}{c}\text { Seed } \\
\text { without oil }\end{array}$ \\
\hline $\mathrm{d}_{\text {app}} \cdot\left(\mathrm{g}^{*} \mathrm{~mL} \mathrm{~L}^{-1}\right)$ & $0,30 \pm 0,01$ & $0,50 \pm 0,01$ & $0,45 \pm 0,01$ \\
\hline RH (\%) & $65 \pm 3$ & $33 \pm 2$ & $56,7 \pm 0,6$ \\
\hline tc (min) & $35 \pm 7$ & $4,5 \pm 0,6$ & $39 \pm 13$ \\
\hline$x_{\mathrm{C}}$ & $0,34 \pm 0,03$ & $0,10 \pm 0,01$ & $0,43 \pm 0,03$ \\
\hline $\mathrm{dm} / \mathrm{dt}\left(\mathrm{mg}^{*} \mathrm{~min}^{-1}\right)$ & $58 \pm 7$ & $62 \pm 6$ & $45 \pm 6$ \\
\hline$A_{\text {flux esp }}\left(\mathrm{m}^{2 *} \mathrm{~kg}^{-1}\right)$ & $1,39 \pm 0,14$ & $0,73 \pm 0,06$ & $0,86 \pm 0,13$ \\
\hline$t_{D}(\min )$ & $83 \pm 19$ & $50 \pm 5$ & $85 \pm 10$ \\
\hline$x_{\mathrm{D}}$ & $0,75 \pm 0,07$ & $0,73 \pm 0,03$ & $0,73 \pm 0,04$ \\
\hline $\mathrm{k}$ esp $\left(\mathrm{s}^{-1 *} \mathrm{~m}^{-2}\right)$ & $36 \pm 3$ & $51 \pm 5$ & $44 \pm 8$ \\
\hline$E_{\text {total }}\left(\mathrm{MJ}^{*} \mathrm{Kg}^{-1}\right)$ & $523 \pm 67$ & $306 \pm 35$ & $470 \pm 33$ \\
\hline $\mathrm{E}_{\text {useful }}\left(\mathrm{MJ}{ }^{*} \mathrm{Kg}^{-1}\right)$ & $1,50 \pm 0,03$ & $0,75 \pm 0,05$ & $1,28 \pm 0,01$ \\
\hline $\mathrm{E} x_{\mathrm{C}}\left(\mathrm{MJ}^{*} \mathrm{Kg}^{-1}\right)$ & $0,26 \pm 0,04$ & $0,14 \pm 0,06$ & $0,31 \pm 0,09$ \\
\hline $\mathrm{E} X_{\mathrm{D}}\left(\mathrm{MJ}^{*} \mathrm{Kg}^{-1}\right)$ & $0,65 \pm 0,12$ & $0,27 \pm 0,04$ & $0,58 \pm 0,05$ \\
\hline $1-E x_{C} / E$ useful & $0,81 \pm 0,03$ & $0,7 \pm 0,1$ & $0,7 \pm 0,1$ \\
\hline $1-E x_{D} / E_{\text {useful }}$ & $0,53 \pm 0,06$ & $0,56 \pm 0,03$ & $0,52 \pm 0,02$ \\
\hline
\end{tabular}

The three parts of the plant are in different curves.

The outer shell shows a high moisture absorption capacity (HR $=65 \%$ ) and a moderate $x_{C}(0,34)$. But it has a high value of its specific fluxional area $\left(1,39 \mathrm{~m}^{2 *} \mathrm{~kg}^{-1}\right)$, which is reflected in a low kinetic constant of region 2, kesp $\left(36 \mathrm{~s}^{-1 *} \mathrm{~m}^{-2}\right)$. The useful drying energy is associated with the high amount of humidity and is relatively high 
$\left(1,5 \mathrm{MJ}^{*} \mathrm{~kg}^{-1}\right)$, thus presenting the high values for the ratios of the energy fractions $\left(1-\mathrm{E} x_{\mathrm{C}} / \mathrm{E}_{\text {useful }}=0,81\right)$ and $\left(1-\mathrm{E} x_{\mathrm{D}} / \mathrm{E}_{\text {useful }}=\right.$ $0,53)$

The inner shell is the one that shows the most interesting characteristics with a low RH $(33 \%)$, low value of $x_{C}(0,10)$ that implies a high porosity with respect to the other parts. Likewise, there is a low specific fluxional area $\left(0,73 \mathrm{~m}^{2} \mathrm{~kg}^{-1}\right)$, a greater $\mathrm{k}_{\mathrm{esp}}$ (51 $\mathrm{s}^{-1 *} \mathrm{~m}^{-2}$ ) and therefore a lower requirement of useful drying energy $(0,75$ $\left.\mathrm{MJ}^{*} \mathrm{~kg}^{-1}\right)$. Although the energy fractions are not different from the outer shell but are somewhat smaller, $\left(1-\mathrm{E} x_{\mathrm{C}} / \mathrm{E}_{\text {useful }}=0,74\right)$ and $\left(1-\mathrm{E} x_{\mathrm{D}} / \mathrm{Euseful}=0,56\right)$

The seed without oil has a good absorption of moisture ( $\mathrm{HR}=57 \%$ ), presenting in contrast a high value of $x_{C}(0,43)$ which implies a low porosity. This is also associated with a specific fluxional area that is intermediate $\left(0,86 \mathrm{~m}^{2 *} \mathrm{~kg}^{-1}\right)$ and similarly the kesp $\left(44 \mathrm{~s}^{-1 *} \mathrm{~m}^{-2}\right)$. This makes the useful drying energy somewhat higher $(1,28$ $\mathrm{MJ}^{*} \mathrm{~kg}^{-1}$ ) and that the energy fractions similar to the internal shell, $\left(1-\mathrm{E} x_{\mathrm{C}} / \mathrm{E}_{\text {useful }}=\right.$ $0,70)$ and $\left(1-E x_{\mathrm{D}} / E_{\text {useful }}=0,52\right)$

The values of $x_{\mathrm{C}}$ are associated with the pore size of the structure, so that the internal shell would have less porosity than the outer shell and the seed without oil (MataSegreda, 2014).

The values of the energy fractions in $x_{C}$ (end of region 1) are of the order of 0,7 to 0,8 and in $x_{\mathrm{D}}$ (end of region 2) present values of the order of 0,6 to 0,5 .

The energy required to reach $x_{C}\left(E x_{C}\right)$, estimated by the Puente-Urbina et al (2015) equation, shows deviations greater than the $5 \%$ expected when the values of $\mathrm{xc}$ are outside the suggested range $(0,20$ to 0,40$)$. In the same way, the values of the energy required to reach $x_{\mathrm{D}}\left(E x_{\mathrm{D}}\right)$. The values of $t_{\mathrm{D}}$ present greater variability due to the longer times between measurements.

On the other hand, the fractions of energy to remove non-superficial water, useful 1-E $x_{\mathrm{C}} / \mathrm{E}_{\text {useful, }}$ are high in all parts of the seed. Being in the order of 0,8 to 0,7 . While the fraction of energy to remove strongly bound water, useful 1-E $x_{\mathrm{D}} / \mathrm{E}_{\mathrm{useful}}$, is in the order of 0,6 to 0,5 .

The different parts of the seed show different drying characteristics. In particular, the internal shell is seen as a biomass different from the rest.

\section{Calorific power, humidity and ashes}

Table 2 shows the values obtained for lower calorific value, \% humidity and \% ash, for samples dried in the yard.

Table 2: Values of calorific power, humidity and ash in castor bean samples

\begin{tabular}{|l|c|c|c|}
\hline \multicolumn{1}{|c|}{ Sample } & $\begin{array}{c}\text { Higher } \\
\text { calorific } \\
\text { power (kJ/g) }\end{array}$ & $\begin{array}{c}\text { Humidity } \\
\text { (\% in mass) }\end{array}$ & $\begin{array}{c}\text { Ashes } \\
\text { (\% in mass) }\end{array}$ \\
\hline Seed without oil & $17,1 \pm 0,3$ & $16,3 \pm 0,5$ & $8,5 \pm 0,4$ \\
\hline Internal Shell & $20 \pm 2$ & $12,1 \pm 0,5$ & $3,3 \pm 0,2$ \\
\hline Outer Shell & $16,6 \pm 0,5$ & $11,8 \pm 0,3$ & $7,1 \pm 03$ \\
\hline
\end{tabular}

According to the bibliography, the lower calorific value of castor biomass residues is around $18 \mathrm{~kJ}^{*} \mathrm{~g}^{-1}$, with a residual humidity of 10 to $12 \%$ and ash of the order of 6 to $7 \%$, both on a dry basis. (Corredor Becerra, 2008; Alexopoulou, et al., 2015) These values are associated with the seed in general without separation of its parts.
In the analysis carried out, values similar to those indicated for the whole of the seed are observed. By differentiating the parts, it can be seen that the internal seed has better values of calorific value $\left(20 \mathrm{~kJ}^{*} \mathrm{~g}^{-1}\right)$, higher density $(0,50)$ and lower values of ash $(3,3$ $\%)$. This could justify their separation process. While the other components have a slightly lower value of their calorific value 
and somewhat higher in their ashes. The residual humidity of the ground seed without oil is somewhat higher than that proposed for the whole seed.

The proportions of the parts of the seed are usually established in percentages by weight of the order of 35-40 / 60-65 shell/seed (Machado, Suárez, \& Alfonso,
2012; Rivera Brenes, 2014). In this case the relation is $30 / 15 / 55$, outer shell, inner shell and seed with oil.

\section{Thermogravimetry (TGA)}

The values obtained by the TGA are presented in Table 3, while a typical figure of the process is presented in Figure 2.

Table 3: Characteristic values of the TGA test

\begin{tabular}{|l|c|c|c|c|}
\hline \multicolumn{1}{|c|}{ Sample } & $\begin{array}{c}\text { Main } \\
\text { Decomposition } \\
\text { Range }(\underline{\circ} \mathrm{C})\end{array}$ & $\begin{array}{c}\text { Mass lost \% in } \\
\text { Principal } \\
\text { decomposition }\end{array}$ & $\begin{array}{c}\text { Humidity } \\
\text { (\% by mass, } \\
\text { on a wet basis })\end{array}$ & $\begin{array}{c}\text { Ashes } \\
\text { (\% by mass, } \\
\text { on a wet } \\
\text { basis })\end{array}$ \\
\hline Seed without oil & $(165$ a 528$)$ & $(31,3$ a 24,7$)$ & $13,6 \pm 0,7$ & $13,4 \pm 0,9$ \\
\hline Internal Shell & $(113$ a 437$)$ & $(40,1$ a 30,5$)$ & $11 \pm 1$ & $10 \pm 4$ \\
\hline Outer Shell & $(135$ a 407$)$ & $(37,6$ a 32,2) & $10,2 \pm 0,7$ & $9 \pm 4$ \\
\hline
\end{tabular}

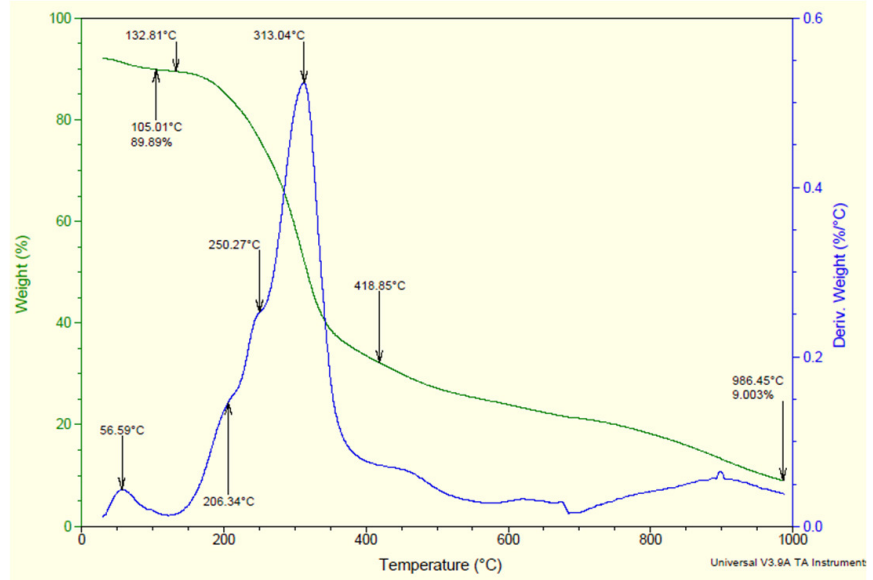

Figure 2: TGA test for the outer shell. Green curve mass variation (mass\%), blue curve derived from the variation of mass with temperature $\left(\% \operatorname{mass} /{ }^{\circ} \mathrm{C}\right)$.

The TGA curves make it possible to observe that the decomposition processes of the parts are similar.

The drying process before $105^{\circ} \mathrm{C}$ presents a peak of the derivative in the environment of 50 to $55^{\circ} \mathrm{C}$ associated with the evaporation of internal water remaining. The loss of mass by drying is of the order of $10 \%$.

The main decomposition occurs from 120 ${ }^{\circ} \mathrm{C}$ with variable environments according to each part of the seed. In the derivative there are 2 to 3 overlapping peaks of decomposition, considered as sequential processes, where the latter is the main and final given its marked decay near $450{ }^{\circ} \mathrm{C}$. The percentage of residual mass after the main decomposition peak is around 30 to 35 $\%$ (Santos N. et al, 2015; Kaur et al., 2018).

The estimated ashes are very variable, but in the order of $10 \%$, being somewhat higher than the values obtained in the calorific power analysis. 


\section{Conclusion}

The analysis carried out shows the possibility of using residues of castor bean as biomass. In particular, the parameters of the internal shell that allow rapid drying with low energy cost and a high value of calorific power and thermal power are of interest. All of which could justify its separation in a specific way during the processing of the castor for the extraction of oil.

\section{Acknowledgement}

We appreciate the support of the company Grial de Costa Rica S.A, who contributed the seeds of castor to the study. The support of the Laboratorio de Nano Tecnología (LANOTEC), of the Centro Nacional de Alta Tecnología (CeNAT), for the development and interpretation of the TGA analysis is also appreciated. Special thanks to Dr. Julio Mata Segreda for his collaboration in interpreting the results.

\section{References}

1. Alexopoulou, E., Papatheohari, Y., Zanetti, F., Tsiostas, K., Papamichael, I., Christou, M., Namatov, I., Monti, A. (2015). "Comparative studies on several castor (Ricinus communis L.) hybrids: Growth, yields, seed oil and biomass characterization," Industrial Crops and Products, 75 (B) 8-13.

2. Corredor Becerra, O. (2008). Evaluación del potencial energético de la biomasa residual proveniente de cultivos energéticos. Bucaramanga, Colombia: Universidad Industrial de Santander, Tesis de Ingeniería Química.

3. da Silva, T. R. G., Pascoal, L. A. F., Costa, F. G. P., Watanabe, P. H., Martins, T. D. D. (2018) Castor bean cake detoxified with calcium hydroxide in diets for pigs at growing and finishing phases, Canadian Journal of Animal Science, 98 (3) 508-516

4. Embrapa Algodão (2015). Empresa Brasileira de Pesquisa Agropecuária, Mamona: Colheita, Beneficiamento e Armazenamento (accessed in july 2017): http://www.cnpa.embrapa.br/produtos/m amona/colheita.html

5. Escoto García, T., Rutiaga Quiñones, J., Orihuela Equihua, R., Rodríguez Rivas, A., \& Rivera Prado, J. (2014). "Estudio químico, micrográfico y morfológico del Ricinus communis L., y su aplicación en pulpa blanqueable," Conciencia Tecnológica, 48 (2) 4-11.

6. Goneli, A. L. D., Correa, P. C., de Oliveira, G. H. H., Resende, O., Mauad, M. (2016) Moisture sorption isotherms of castor beans. Part 1: Mathematical modeling and hysteresis, Revista Brasileira de Engenharia Agricola e Ambiental, 20 (8) 751-756

7. Geankoplis, C. (2003). Procesos de Transporte y Operaciones Unitarias (3a ed.). Compañía Editorial Continental, México, México.

8. Karmakar, B., Dhawane, S.H., Halder, G. (2018) Optimization of biodiesel production from castor oil by Taguchi design, Journal of Environmental Chemical Engineering, 6 (2) 2684-2695

9. Kaur, R., Gera, P., Jha, M.K., Bhaskar, T. (2018) Pyrolysis kinetics and thermodynamic parameters of castor (Ricinus communis) residue using thermogravimetric analysis, Bioresource Technology, 250, 422-428

10. Machado, R., Suárez, J., \& Alfonso, M. (2012). "Morphological and agroproductive characterization of Ricinus communis $\mathrm{L}$. provenances for oil production," Pastos y Forrajes, 35 (4) 381-394.

11. Mata-Segreda, J. (2014). "Drying kinetics as a new tool for the estimation of pore size of materials," UNED Research journal, 6 (1) 149-152.

12. Puente-Urbina, A., Morales-Aymerich, J., Sing Kim, Y., \& Mata-Segreda, J. (2016). "Drying kinetics and assessment of relative energy cost for drying of woody biomasses," International journal of renevable energy and biofuels, 2016 (2016), Article ID 701233. doi:10.5171/2016.701233 
13. Rivera Brenes, P. (2014). Evaluación agronómica de 7 variedades de higuerilla (Ricinus Communis) como alternativa en la producción de bioenergía. San José, Costa Rica: UNED, Tesis de Ingeniería Agronómica.

14. Salazar Sánchez, L., Rosales Serna, R., Jiménez Ocampo, R., Rios Saucedo, J., Sigala Rodríguez, J., Carrillo Parra, A., Domínguez Martínez, P. A., Martínez Fernández, M. (2015). “Optimizing calorific value in plant species showing potential for dendroenergetic biomass production, in Durango, Mexico," Agrofaz, (1) 147-154.
15. Sánchez S., M., Castañeda S., R., \& Castañeda S., M. (2016). "Usos y potencialidad de la Higuerilla (Ricinus communis) en sistemas agroforestales en Colombia," PUBVET, 10 (6) 507-512.

16. Santos, N.A.V., Magriotis, Z.M., Saczk, A.A., Fássio, G.T.A., Vieira, S.S. (2015) Kinetic study of pyrolysis of castor beans (Ricinus communis L.) presscake: An alternative use for solid waste arising from the biodiesel production, Energy and Fuels, 29 (4) 23512357. 